ABDI: Jurnal Pengabdian dan Pemberdayaan Masyarakat ISSN: 2656-369X (Print), 2684-8570 (Online)

Volume 1 No. 2, Desember 2019

http://abdi.ppj.unp.ac.id/index.php/abdi

Email: abdi@ppj.unp.ac.id

DOI: https://doi.org/10.24036/abdi.vli2.22

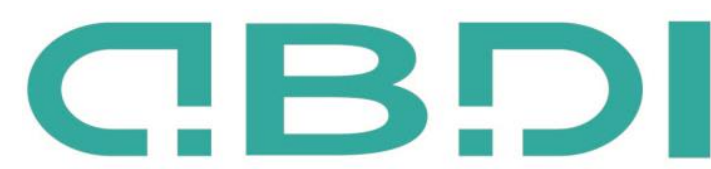

ABDI: JURNAL PENGABDIAN DAN PEMBERDAYAAN MASYARAKAT

\title{
Pengembangan Self-Efficacy Pelajar Melalui Pendidikan Seks Dini Guna Mencegah Pelecehan Seksual Pada Anak
}

\author{
Lailatur Rahmi \\ Jurusan Geografi Universitas Negeri Padang \\ Email: lailaturrahmi@fis.unp.ac.id
}

\begin{abstract}
Abstrak
Melalui pengembangan Self-Efficacy dapat meningkatkan pengetahuan pelajar sekolah dasar tentang organ reproduksi dan kesehatan reproduksi guna memproteksi diri mereka dari tindakan pelecean seksual, serta memberikan pemahaman dan kesadaran kepada pelajar sekolah dasar mengenai bahaya dan resiko bencana pelecehan seksual, meningkatkan kepedulian mereka terhadap pengaruh lingkungan yang buruk dengan mengembangkan Self Efficacy sebagai salah satu upaya dalam menngurangi resiko pelecehan seksual. Pelecehan seksual sebagai bagian dari kekerasan seksual juga seringkali terjadi pada anak-anak dan sebagian besar korban pelecehan seksual adalah anak-anak dan remaja perempuan yang berusia di bawah 18 tahun, masih berstatus sebagai pelajar, dengan status sosial ekonomi keluarga dalam kalangan menengah ke bawah. Hal ini menunjukkan kondisi anak yang rentan menjadi korban pelecehan seksual dan dikhawatirkan akan berdampak buruk terhadap perkembangan anak pada tahap selanjutnya. Dampak psikologis yang dialami korban pelecehan seksual akan menyebabkan mereka cenderung menyendiri, dikucilkan dalam pergaulan masyarakat, dikeluarkan dari sekolah, menyalahkan diri sendiri, dan trauma berkepanjangan.
\end{abstract}

Kata Kunci: Pendidikan Seks Dini, Pelecehan Seksual, Self-Efficacy,

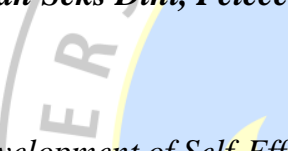

\section{Abstract}

Through the development of Self-Efficacy can improve the knowledge of elementary school students about reproductive organs and reproductive health to protect themselves from sexual action, as well as to provide understanding and awareness to students Elementary school regarding the dangers and risks of sexual harassment, increased their awareness of the poor environmental impact by developing Self Efficacy as one of the efforts to promote the risk of sexual harassment. Sexual harassment as part of sexual violence also often occurs in children and most of the victims of sexual abuse are children and young women under the age of 18, still as students, with Socio-economic families in middle-to-lower circles. This shows the condition that vulnerable children become victims of sexual harassment and are feared to have a bad impact on child development at a later stage. The psychological impacts of sexual abuse victims will cause them to be solited, excluded in community associations, expelled from school, self-blame, and prolonged trauma.

Keyword: Early sex education, Self-Efficacy, Sexual harassment

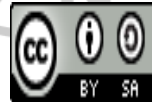





\section{Pendahuluan}

Perkembangan jaman yang semakin pesat tidak hanya membawa dampak positif bagi kehidupan manusia namun juga menimbulkan berbagai masalah baru yang sulit untuk dihindari. Termasuk masalah anak pun menjadi semakin kompleks. Salah satu masalah yang mengintai anak-anak adalah kasus kekerasan seksual pada anak. Berdasarkan data Komisi Perlindungan Anak Indonesia (KPAI) disebutkan bahwa anak sebagai korban kekerasan seksual pada tahun 2014 sebanyak 656 kasus, tahun 2015 sebanyak 218 kasus, dan pada tahun 2016 sebanyak 156 kasus per Oktober 2016. Sedangkan data terkait anak sebagai pelaku kekerasan seksual yaitu pada tahun 2014 terdapat 561 kasus, tahun 2015 terdapat 157 kasus, dan pada tahun 2016 terdapat 107 kasus per Oktober 2016. Data tersebut menunjukkan masih banyaknya tindak kekerasan seksual pada anak baik sebagai korban maupun pelaku. Di Indonesia kasus pelecehan seksual terhadap anak semakin meningkat, dan tidak mengenal batas usia, pelecehan seksual banyak dilakukan oleh pihak yang paling dekat dengan anak atau korban, sehingga hal ini menjadi perhatian yang serius. UNICEF mengungkapkan bahwa sekitar 120 juta anak di seluruh dunia atau lebih dari 100 anak telah menjadi korban pelecehan seksual di bawah usia 20 tahun. Ketua Komisi Nasional Perlindungan Anak Indonesia (KPAI) menyampaikan bahwa di tahun 2013 terdapat 925 kasus pelecehan seksual terhadap anak yang telah ditangani oleh KPAI, pelaku dimulai dari kerabat, guru, teman temannya. Bahkan ditiga tahun terakhir ini sejumlah 3500-3600 kasus yang ditangani oleh KPAI.

Pelecehan yang menimpa anak-anak, baik dari keluarga, sekolah, maupun lingkungan sekitar, terus mengalami peningkatan dari tahun ke tahun. Mirisnya, sebagian besar pelaku pelecahan seksual adalah orang yang dikenal oleh korban mereka; sekitar 30\% adalah keluarga dari si anak, paling sering adalah saudara laki-laki, ayah, paman, atau sepupu; sekitar $60 \%$ adalah kenalan lainnya seperti 'teman' dari keluarga, pengasuh, atau tetangga, orang asing adalah pelanggar sekitar $10 \%$ dalam kasus penyalahgunaan seksual anak (Elizabeth, 2013). Tingginya pelecehan pada anak memperlihatkan bahwa persoalan kekerasan menjadi persoalan yang amat serius, apalagi kekerasan tersebut dilakukan oleh orang tua sendiri maupun orang yang dekat dengan anak. Dimana orangtua dan guru seharusnya menjadi seorang yang paling bertanggung jawab atas tumbuh dan berkembangnya anak karena keluarga merupakan lingkungan pertama bagi anak untuk belajar dan menyatakan diri sebagai mahluk sosial.

Data Komisi Perlindungan Anak menyatakan bahwa Provinsi Sumatera Barat pada tahun 2018 terdapat 229 kasus kekerasan dan 52\% diantaranya adalah dikarenakan pelecehan seksual. (www.covesia.com). Begitu pula yang terjadi di Nagari Sungai Jambu Kecamatan Pariangan Kabupaten Tanah Datar, selama 1 tahun terakhir, pelecehan seksual terhadap anak, terutama anak sekolah dasar mengalami peningkatan. Pelecehan ini dilakukan kepada anak sekolah dasar kelas 5 kebawah, mereka yang belum paham dan mengenal kesehatan reproduksi mereka bagaimana, tapi sudah diperlakukan tidak wajar oleh orang dewasa, dan kebanyakan pelaku adalah orang-orang terdekat korban atau mereka yang sudah mengenal korban dari lama. Pelecehan ini dilakukan tidak hanya satu kali bahkan sampai berkali-kali dengan diiming-imingkan uang dan permen oleh pelaku. Korban yang tidak tau apa yang dilakuka oleh pelaku hanya membiarkan begitu saja anggota tubuhnya dipegang-pengang oleh orang lain, sehingga pelecehan ini menjadi mudah untuk dilakukan.

Pelecehan seksual ini terungkap ketika siswa SD (korban) hendak buang air kecil, kemudian merasakan sakit dibagian kemaluan, dan baru menceritakan kejadian tersebut kepad orang tuan dan keluarga, sehingga baru dilakukan tindak lanjut. Untuk mencegah hal ini kembali terjadi pada siswasiswa lainnya, maka dibutuhkan Self-Efficacy kepad pelajar SD dengan mengenalkan kepada mereka tentang kesehatan reproduksi serta bagian tubuh mana yang tidak boleh dipegang oleh siapapun kecuali orang tua atau ibu dan ayah. Dengan adanya kegiatan ini diharapkan pelajar SD semakin mampu memproteksi diri mereka dari bahaya-bahaya yang akan menggangu dan mengancam keselamatan mereka, terutama terkait dengan pelecehan seksual, sehinga mereka mampu mengantisipasi permasalahan ini. 


\section{Metode Pelaksanaan}

Kegiatan ini dilaksanakan di Sekolah Dasar Negeri di Kenagarian Sungai Jambu. Sekolah ini dipilih dikarenakan kasus pelecehan seksual kepada anak sering terjadi didaerah ini, sehingga hal ini sudah sangat meresahkan masyarakat sekitar. Metode yang digunakan dalam kegitan ini adalah:

\section{Studi Kasus}

Studi kasus dilakukan dengan meninjau kasus-kasus atau persoalan yang tengah dihadapi ditengahtengah masyarakat. Terutama persoalan yang berhubungan dengan pelecehan seksual.

2. Praktek/Peragaan

Praktek atau peragaan ini merupakan proses dari salah satu indikator kemampuan pelajar dalam menyerap materi yang diberikan dalam pelatihan. Praktek dilakukan untuk materi yang bersifat ketrampilan, misalnya pengenalan organ tubuh kepada pelajar sekolah dasar.

3. Brain Storming

Brainstorming merupakan proses pengumpulan gagasan secara bersama-sama dan menjadikan suatu inventarisasi terhadap gagasan yang dikemukakan. Brainstorming ini bagus diulas saat diadakan sesi tanya jawab pada pelaksanaan pelatihan.

4. Diskusi/Tanya jawab

Diskusi merupakan proses yang dilakukan untuk membahas masalah-masalah yang ditemui dan dihadapi oleh masyarakat di lapangan.

\section{Hasil dan Pembahasan}

Seseorang dengan Self-Efficacy yang tinggi percaya bahwa mereka mampu melakukan sesuatu untuk mengubah kejadian-kejadian sekitarnya, sedangkan seseorang dengan Self-Efficacy yang rendah menganggap dirinya pada dasarnya tidak mampu mengerjakan segala sesuatu yang ada disekitarnya. Dalam situasi yang sulit orang dengan Self-Efficacy yang rendah cenderung akan mudah menyerah. Sementara Self-Efficacy yang tinggi akan berusaha lebih keras menghadapi tantangan yang ada. SelfEfficacy berbeda dengan aspirasi, karena cita-cita menggambarkan sesuatu yang ideal yang seharusnya (dapat dicapai), sedangkan Self-Efficacy menggambarkan penilaian kemampuan diri. (Alwisol, 2007).

Pendidikan seks usia dini lebih menekankan bagaimana memberikan pemahaman kepada anak akan kondisi tubuhnya, pemahaman akan lawan jenis dan pemahaman untuk menghindarkan diri dari pelecehan seksual. Pendidikan seks yang dimaksudkan adalah anak mulai mengenal akan identitas diri dan keluarga, mengenal anggota tubuh mereka, serta dapat menyebutkan ciri-ciri tubuh. Pendidikan seks usia dini seyogyanya diberikan secara bertahap sesuai dengan tingkat pemahaman dan usianya. Setiap anak memiliki cara pemahaman yang berbeda terhadap pendidikan seks. Penerapan pendidikan seks dini pada anak melalui beberapa tahap antara lain:

Pertama, menanamkan rasa malu pada anak. Rasa malu harus ditanamkan kepada anak sejak dini. Jangan biakasan anak-anak, meskipun masih kecil, bertelanjang didepan orang lain, seperti keluar kamar mandi, berganti pakaian dll. Membiasakan anak perempuan sejak kecil berusaha berbusana muslimah menutup aurat serta menanamkan rasa malu sekaligus mengajari anak tentang auratnya. Kedua, memberikan pengetahuan kepada anak tentang alat-alat reproduksi mereka, perbedaan antara reproduksi laki-laki dan perempuan, serta memberikan penjelasan yang detail kepada anak siapa-siapa saja yang boleh dan tidak boleh memengang tubuh mereka. Ketiga, menanamkan jiwa maskulinitas pada anak laki-laki dan jiwa feminitas pada anak perempuan. Secara fisik dan psikis, laki-laki dan perempuan mempunyai perbedaan mendasar. Harus membiasakan anak sedari kecil berpakain sesuai dengan jenis kelamin. Mereka harus diperlakukan sesuai dengan jenis kelaminnya. Keempat, mengajarkan anak agar tempat tidur antara anak laki-laki dengan perempuan harus dipisahkan. Usia antara 7-10 tahun merupakan usia saat anak mengalami perkembangan yang pesat. Anak mulai melakukan eksplorasi ke dunia luar dirinya. Pemisahan tempat tidur dilakukan terhadap anak dengan 
saudaranya yang berbeda jenis kelamin, secara langsung ia telah menumbuhkan kesadarannya tentang eksistensi perbedaan jenis kelamin.

Kelima, mengenalkan waktu berkunjung (meminta izin dalam 3 waktu). Tiga ketentuan waktu yang tidak diperbolehkan anak-anak untuk memasuki ruangan (kamar) orang dewasa, kecuali meminta izin terlebih dahulu yaitu sebelum sholat subuh, tengah hari, dan setelah shalat isya. Jika pendidikan ini ditananmkan pada anak, mereka akan menjadi anak yang memiliki rasa sopan-santun dan etika yang luhur. Keenam, mendidik anak agar menjaga kebersihan alat kelamin. Mengajari anak untuk menjaga kebersihan alat kelamin selain agar bersih dan sehat sekaligus juga mengajari anak tentang najis. Anak dibiasakn untuk buang air pada tempatnya. Sehingga akan terbentuk pada diri anak sikap hati-hati, mandiri, mencintai kebersihan, mampu menguasai diri, disiplin dan sikap moral yang memperhatikan tentang etika sopan santun dalam melakuna hajat. Ketujuh, membatasi aktivitas menonton anak, tayangan yang dipertontonkan kepada anak tidak semuanya bernilai pendidikan, banyak tayangan yang menampilkan adegan-adegan yang belum pantas dilihat oleh anak-anak. Hal ini akan mengakibatkan anak meniru adegan yang ada didalam tontonannya. Dengan membatasi aktivitas menonton anak orang tua mampu memantau tonton anak serta mengarahkan mereka untuk hal-hal yang positif. Memberikan pemahaman dan penjelasan kepada anak tentang pendidikan seks dini, diharapkan anak akan mampu melindungi diri mereka sendiri, karena dengan mengetahui bagian tubuh mana yang boleh dan tidak boleh dipegang oleh orang lain selain dari ibu sendiri, membuat anak lebih waspada terhadap orang lain yang ingin mecoba memegang dan meraba tubuh mereka. Dengan meningkatkan Self-Efficacy ini akan membuat anak lebih berani melindungi diri sendiri serta lebih berani memprotes orang-orang yang melanggar pemahaman yang ditananamkan kepada mereka, sehingga hal ini diharapkan mampu meminimalisir pelecehan seksual terhadap anak.

\section{Kesimpulan}

Peningkatan Self-efficacy Upaya yang dapat dilakukan untuk mencegah pelecehan seksual pada anak antara lain menanakan rasa malu kepada anak, menanakan jiwa maskulin bagi anak laki-laki, dan menanamkan jiwa feminimisme bagi anak wanita, memisahkan tempat tidur antara anak laki-laki dan anak perempuan, mengenalkan waktu berkunjung, mendidik anak untuk menjaga kebersihan alat kelamin, dan membatasi waktu menonton anak. Dengan menanamkan self-efficacy ini diharapkan anak mampu memproteksi diri mereka dari orang lain yang ingin menggangu dirinya. Penulis mengucapkan terimakasih kepada semua pihak yang terlibat dalam kegiatan ini, kepada Kepala Sekolah Dasar seKenagarian Sungai Jambu, Guru-guru serta semua murid sekolah dasar se-Kenagarian Sungai Jambu dan anggota semua tim peneliti.

\section{Daftar Pustaka}

Alwisol, Roqib. (2007). Psikologi Kepribadian. Malang: Penerbit UPT Universitas Muhammadiyah Malang.

Elizabeth M. Molyneux, Neil Kennedy, Asefa Dano, Yabwile Mulambia (2013). Sexual Abuse of Children in Low-income Settings: Time for action. Paediatrics and International Child Health, 33(1), 239-246.

Komisi Perlindungan Anak Indonesia. (2014). Upaya Peningkatan Anak dari Bahaya Kekerasan, Pelecehan dan Ekploitasi

Kartono, Kartini. (1981). Psychologi Wanita, gadis Remaja, dan Wanita Dewasa. Bandung:

Huraerah, Abu. (2006). Kekerasan Terhadap Anak. Jakarta: Nuansa.

Lagan, C. (2014). Sexual harassment or sexual assault? Do you know the difference? allhands.coastguard.dodlive.mil/

Pendidikan Seks (Sex Education) Sejak Dini...Kenapa Tidak???. dokterkecil.wordpress.com/. Diakses tangal 11 Nopember 2019

Riany, Y.E. (2014). Melacak Akar Kekerasan Seksual Terhadap Anak. https//: plus.google.com Diakses tangal 11 Nopember 2019 